\title{
The Mid Atlantic Appalachian Orogen Traverse: a comparison of virtual and on-location field-based capstone experiences
}

\author{
Steven Whitmeyer ${ }^{1}$, Lynn Fichter ${ }^{1}$, Anita Marshall ${ }^{2}$, and Hannah Liddle ${ }^{1}$ \\ ${ }^{1}$ Department of Geology and Environmental Science, James Madison University, Harrisonburg, VA 22807, USA \\ ${ }^{2}$ Department of Geological Sciences, University of Florida, Gainesville, FL 32611-2120, USA
}

Correspondence: Steven Whitmeyer (whitmesj@jmu.edu)

Received: 27 August 2021 - Discussion started: 3 September 2021

Revised: 29 November 2021 - Accepted: 30 November 2021 - Published: 23 December 2021

\begin{abstract}
The Stratigraphy, Structure, Tectonics (SST) course at James Madison University incorporates a capstone project that traverses the Mid Atlantic region of the Appalachian Orogen and includes several all-day field trips. In the Fall 2020 semester, the SST field trips transitioned to a virtual format, due to restrictions from the COVID pandemic. The virtual field trip projects were developed in web-based Google Earth and incorporated other supplemental PowerPoint and PDF files. In order to evaluate the effectiveness of the virtual field experiences in comparison with traditional on-location field trips, an online survey was sent to SST students that took the course virtually in Fall 2020 and to students that took the course in person in previous years. Instructors and students alike recognized that some aspects of on-location field learning, especially those with a tactile component, were not possible or effective in virtual field experiences. However, students recognized the value of virtual field experiences for reviewing and revisiting outcrops as well as noting the improved access to virtual outcrops for students with disabilities and the generally more inclusive experience of virtual field trips. Students highlighted the potential benefits for hybrid field experiences that incorporate both onlocation outcrop investigations and virtual field trips, which is the preferred model for SST field experiences in Fall 2021 and into the future.
\end{abstract}

\section{Introduction}

On-location field trips and field experiences are a traditional component of undergraduate geoscience curricula. However, the onset of the COVID-19 pandemic in early 2020 resulted in quarantine restrictions that inhibited on-location fieldwork and field-based educational experiences for a substantial period of time. This left many geoscience departments scrambling to find alternative field experiences for courses that traditionally incorporated field-oriented educational components (e.g., Bond and Cawood, 2021; Bosch, 2021; Gregory et al., 2021; Quigley, 2021; Rotzien et al., 2021). In many departments, alternatives to on-location field trips focused on virtual field experiences (VFEs), where geologic content and concepts that traditionally focused on physical outcrops were delivered online using an assortment of digital platforms. However, with the transition to virtual field experiences it is not clear how effective VFEs are in comparison to on-locations field trips nor is it apparent how student learning is impacted. In this contribution we document how a series of on location field trips were migrated to VFEs, and we present preliminary data from instructors and students on the effectiveness of VFEs in comparison with on-location field experiences.

The necessity for transitioning undergraduate field experiences to virtual formats due to pandemic restrictions led to a grassroots effort by geoscience educators to assemble examples of virtual field experiences in a publicly accessible web portal for use by the community (Egger et al., 2021). The National Association of Geoscience Teachers (NAGT) Teach the Earth portal developed a new site, entitled "Teaching with Online Field Experiences", to host an array of virtual field experiences and teaching modules. These range from introductory field trips to capstone projects at virtual field sites around the globe and beyond (https://serc. carleton.edu/NAGTWorkshops/online_field/index.html, last access: 21 December 2021). Like other geoscience depart- 


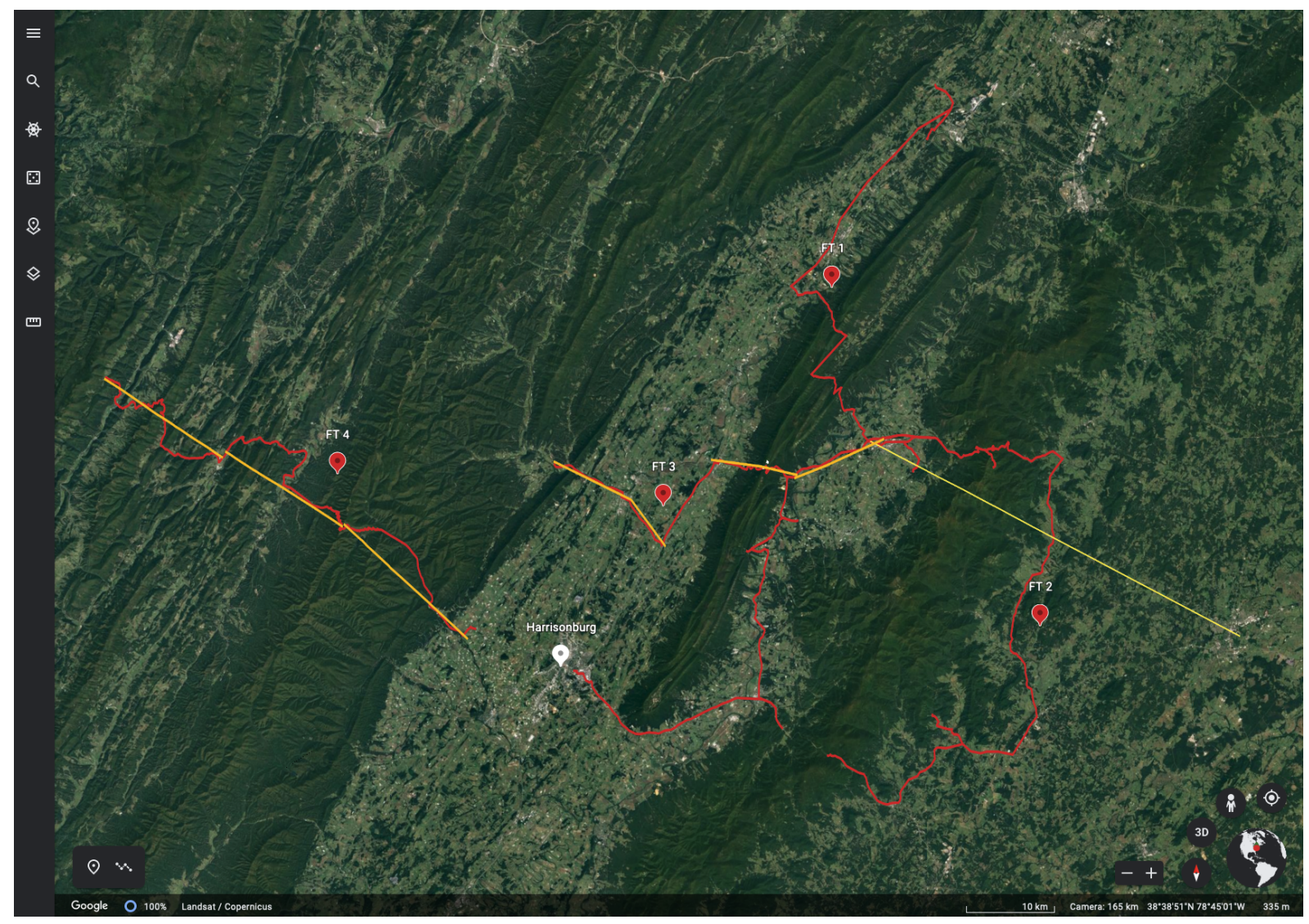

Figure 1. Screen image showing locations of web-based ( ) Google Earth virtual field trips in eastern West Virginia and western Virginia from the Mid Atlantic Appalachian Orogen Traverse project; red lines indicate the paths of each field trip (labeled FT1, FT2, FT3, FT4), and the yellow lines show the locations for each cross section that students draft for the project.

ments in the US and Europe, the James Madison University (JMU) Department of Geology and Environmental Science was significantly impacted by pandemic-based field restrictions. JMU instructors for courses in Fall 2020 had to rethink how to conduct the field components of their respective curricula in a virtual environment and looked to the NAGT Teaching with Online Field Experiences portal for ideas and inspiration.

Among the JMU geoscience courses typically taught in the Fall semester is an upper-level course, entitled Stratigraphy, Structure, Tectonics (or SST), that incorporates basic principles of stratigraphy and basin analysis along with methods of structural analysis, within the framework of models of the regional tectonic history and the Wilson Cycle (Wilson, 1966; Burke and Dewey, 1974). The course culminates with a multi-week capstone project, where students spend $5 \mathrm{~d}$ in the field collecting stratigraphic and structural data and interpret this data in the context of the Appalachian Orogen in the Mid Atlantic region of western Virginia and eastern West Virginia (Fichter et al., 2010; Fig. 1). This area is a classic example of relatively thin-skinned, fold and thrust belt tectonics (e.g., Perry, 1978; Evans, 1989) as well as display- ing abundant evidence of earlier depositional environments (e.g., Cooper and Cooper, 1945; Dennison and Head, 1975). Most of the visible, outcrop-scale deformation in the region resulted from the Alleghanian orogeny (Bartholomew and Whitaker, 2010; Whitmeyer et al., 2015), although the Blue Ridge geologic province preserves deformation and fabrics that derived from the Grenville orogenic cycle, along with younger Neo-Acadian high-strain zones (Bailey et al., 2006; Southworth et al., 2010). In contrast, stratigraphic data from the field trips provide evidence for earlier tectonic events, such as the Ordovician Taconic orogeny (e.g., Diecchio, 1993) and the Devonian Acadian Orogeny (e.g., McClung et al., 2013). Students use stratigraphic and structural field data that they collect on the field trips to draft a series of interpretive cross sections across the Blue Ridge and Valley and Ridge geologic provinces and then synthesize their data and interpretations in a report that describes the tectonic history of the region from the Mesoproterozoic Grenville orogeny through the Paleozoic assembly of Pangaea (Whitmeyer and Fichter, 2019).

The SST field trips that encompass the Mid Atlantic Appalachian Orogen Traverse (MAAOT) project typically con- 
sist of five all-day trips on weekends and focus on roadcuts or easily accessible outcrops along a generally east-to-west transect, roughly perpendicular to the regional strike (Fig. 1). Students work in teams to collect lithologic and orientation data from each field trip site and then spend time in discussions with their colleagues and instructors to place the local outcrop data into a regional tectonic context. In general, information from igneous and metamorphic rocks provides data for the Grenville orogenic cycle, stratigraphic data provide the bulk of the evidence for interpreting the Taconic and Acadian orogenies, and structural and orientation data provide information for interpreting the Alleghanian orogeny. Some specific field locations also provide data and information relevant to the breakup of the Rodinia or the Pangaea supercontinents. The SST field trips are sequenced as follows:

- Field Trip 1. This field trip functions as an introduction to Cambrian-Ordovician sedimentary units of the Valley and Ridge geologic province, in the contexts of the rifting of Rodinia, formation of the Iapetan divergent continental margin, and the subsequent Taconic orogeny. Students are introduced to methods of stratigraphic data collection, analysis, and principles of basin evolution.

- Field Trip 2. This field trip focuses on rocks of the Blue Ridge geologic province, and students collect data on igneous and metamorphic composition and textures, stratigraphic and sedimentological features, and structural/deformation features. The tectonic context includes the Grenville orogeny and two stages of the rifting of Rodinia.

- Field Trip 3. This field trip progresses westward across the eastern part of the Valley and Ridge geologic province, effectively linking with the northwestern end of Field Trip 2. Students primarily collect data on stratigraphic features of Ordovician (Taconic clastic wedge and subsequent orogenic calm) to Devonian (Acadian clastic wedge and foreland basin) sedimentary rocks and later structural/deformational features associated with the Alleghanian orogeny.

- Field Trips 4 and 5. These field trips traverse the middle and western parts of the Valley and Ridge geologic province, ending at the Allegheny deformational front in West Virginia. The eastern end of the traverse is along-strike with the western end of Field Trip 3. The traverse is divided into two field trips, as the distance covered and the number of stops visited take up too much time for a single day's field trip. Students again collect data on Paleozoic stratigraphic and structural features and evaluate depositional environments and tectonic events from the Cambrian through the Carboniferous periods.
On each of the first two field trips, student teams synthesize their field observations into summaries of the geology and interpretations of the tectonic history of the region traversed by each field trip. These tectonic synthesis reports are evaluated and commented on by instructors and returned to the students as iterative drafts of the final tectonic summary report that student teams produce at the end of the multi-week project. Following the second and subsequent field trips, student teams draft interpretive cross sections along each field trip route, approximately perpendicular to the NNE-SSW regional strike. Similar to the summary reports, these draft cross sections are each evaluated and commented on by professors and returned to the students as iterative drafts of the series of cross sections that collectively traverse the Appalachian orogen in the Mid Atlantic region, which the students produce as part of their final project deliverables (see Whitmeyer and Fichter, 2019, for more details on the project and deliverables). Through this iterative approach of collecting field data, drafting cross section interpretations of the geology, and interpreting geologic data and models in a summary report, students gain experience with data collection, interpretation, and synthesis - key components of higherorder thinking in Bloom's taxonomy (Bloom et al., 1956; Anderson et al., 2001).

\section{The transition to virtual field trips}

Due to the COVID restrictions on travel, field trips for the Fall 2020 SST course had to transition to a virtual format. There are several digital platforms that can be used to display spatial and geologic data in an interactive format (Google Earth, ArcGIS, Unity game engine, etc.); SST instructors used the web-based version of Google Earth to host virtual field trips for the MAAOT, primarily for its ease of use and near-universal availability across a variety of computer hardware and mobile devices (see https://www.google.com/earth/ versions/, last access: 21 December 2021, for more information). Each of the standard on-location SST field trips was redesigned as a Google Earth project that incorporated field trip sites in the general sequence that would be visited during a standard on-location field trip. The virtual Google Earth environment also facilitated the inclusion of extra field locations which there would not normally be enough time to visit during a typical on-location weekend field trip. The four virtual field trips and associated materials that encompass the MAAOT are accessible via the links below:

- Field Trip 1: stratigraphic sequences of the Valley and Ridge province;

- Field Trip 2: virtual field trip to the Blue Ridge province, central Virginia;

- Field Trip 3: Rt. 211/259 transect;

- Field Trip 4: Rt. 33 transect. 
The links above access field trip modules that are included on the NAGT Teaching with Online Field Experiences web portal (https://serc.carleton.edu/NAGTWorkshops/online_field/ index.html, last access: 21 December 2021). The modules follow the general format of other VFEs on the web portal, starting with a summary of the exercise, followed by sections on the overall context of the field experience, the educational goals, the technology requirements, useful teaching notes and tips, and assessment strategies. Each module web page includes a link to the relevant Google Earth (GE) field trip along with exercise handouts, supplementary materials ("chalk talk" PowerPoint files), and other supporting documents.

The web-based GE platform used for these modules, though lacking some of the components of the downloadable desktop version of Google Earth Pro, has many features that make it ideal for hosting interactive virtual geology field trips. Chief among these is that web-based GE projects are hosted on the creator's Google Drive site and thus can be easily shared with students via a standard browser link (e.g., https://earth.google.com/web/@38.51046688,78.25665862,349.1675803a,83138.43633292d,30y,0h,0t,0r/, last access: 21 December 2021). Thus, in contrast to Google Earth Pro, web GE projects also can be interactively viewed on mobile devices. Web GE projects can be designed to sequentially highlight stops along a virtual field trip (Fig. 2a) and can also include a full-screen title slide at the start of a presentation (Fig. 2b) to introduce the project and orient the user.

\subsection{Designing virtual field trips in web GE}

Field trip locations can be highlighted with standard GE placemark pins or with multi-node lines, such that strike and dip symbols can be drawn at an outcrop location, thereby replicating features of a standard geologic map (Fig. 3a). Each slide (i.e., field site) of a GE project can be tailored to show a zoomed in bird's-eye or oblique view of the location or a zoomable and rotatable Street View image of the actual outcrop (if Street View imagery is available for that location; Fig. 3b). Each slide can incorporate a pop-up box with descriptive text and an image carousel that can sequentially display up to eight images or videos. Clicking on an image in the box will display an enlarged version of the image, which is useful for showing annotations and details of outcrop features (e.g., Fig. 3c). Short explanatory videos can also be included in the image carousel (e.g., Fig. 3d), as long as the videos are hosted on YouTube and made available for public viewing. Details on how the virtual field trips were designed and constructed in GE can be found in Whitmeyer and Dordevic (2021), which highlights a virtual field trip across the Blue Ridge province in Virginia (Field Trip 2 of the MAAOT) as an example.

\subsection{Implementing virtual field trips}

The SST virtual field trips were conducted in a format that replicated the organization of an on-location field trip, minus the driving from stop to stop. Students and instructors (field trip leaders) assembled online using the Zoom virtual meeting platform, and each participant had access to virtual field trip materials, including the GE field trip project, PowerPoint files of supplementary materials, and other handouts as PDF files. Instructors used the screen sharing mode of Zoom to virtually visit each GE field trip site, show outcrop photos and other imagery in GE, and, at some locations, show more detailed chalk talks of images and background concepts using PowerPoint. The concept of chalk talks derives from on-location field trips, where a field trip leader would use a chalk board or a whiteboard to illustrate specific features or concepts relevant to a given field location. For on-location field trips, SST students were provided with a packet of paper handouts that consisted of annotated images and theoretical models as supporting materials for the chalk talk discussions. Given the GE restriction of only eight slides in the image carousel, for the virtual field trips chalk talk materials were provided as supplementary PowerPoint and/or PDF files that included images, diagrams, and models.

On virtual field trips in SST, interactive explanations, discussions, and queries about the geology of each site were conducted on Zoom in a similar format to on-location field stops. Short breaks were taken every couple of hours between stops to avoid Zoom fatigue, recognizing that downtimes in on-location field trips that occurred during travel from stop to stop do not occur during virtual field trips. A longer lunch break was also included, again replicating a traditional field experience (minus the visit to the grocery store or restaurant). Overall, even with frequent breaks, each virtual field trip typically took less time than its on-location counterpart, likely due to the elimination of the time needed for travel along the field trip route.

\section{Experiences with virtual field trips}

STEM educators recognize that teaching and learning in a virtual environment can be dramatically different from in-person interactions between instructors and students (e.g., Humphrey and Wiles, 2021), although instructors and students often recognize the value of virtual education environments (Mikropoulos and Natsis, 2021). Challenges in virtual education are apparent in situations where direct observations, interactive discourse, and hypothesis testing are highlighted as essential components of field-focused learning (Hurst, 1998; Mogk and Goodwin, 2012). Kastens et al. (2009) note the value of guided apprenticeship between field instructors and students, which can be especially difficult to achieve in virtual field experiences that are designed for student-centered inquiry (Jacobson et al., 2009; Mead et 


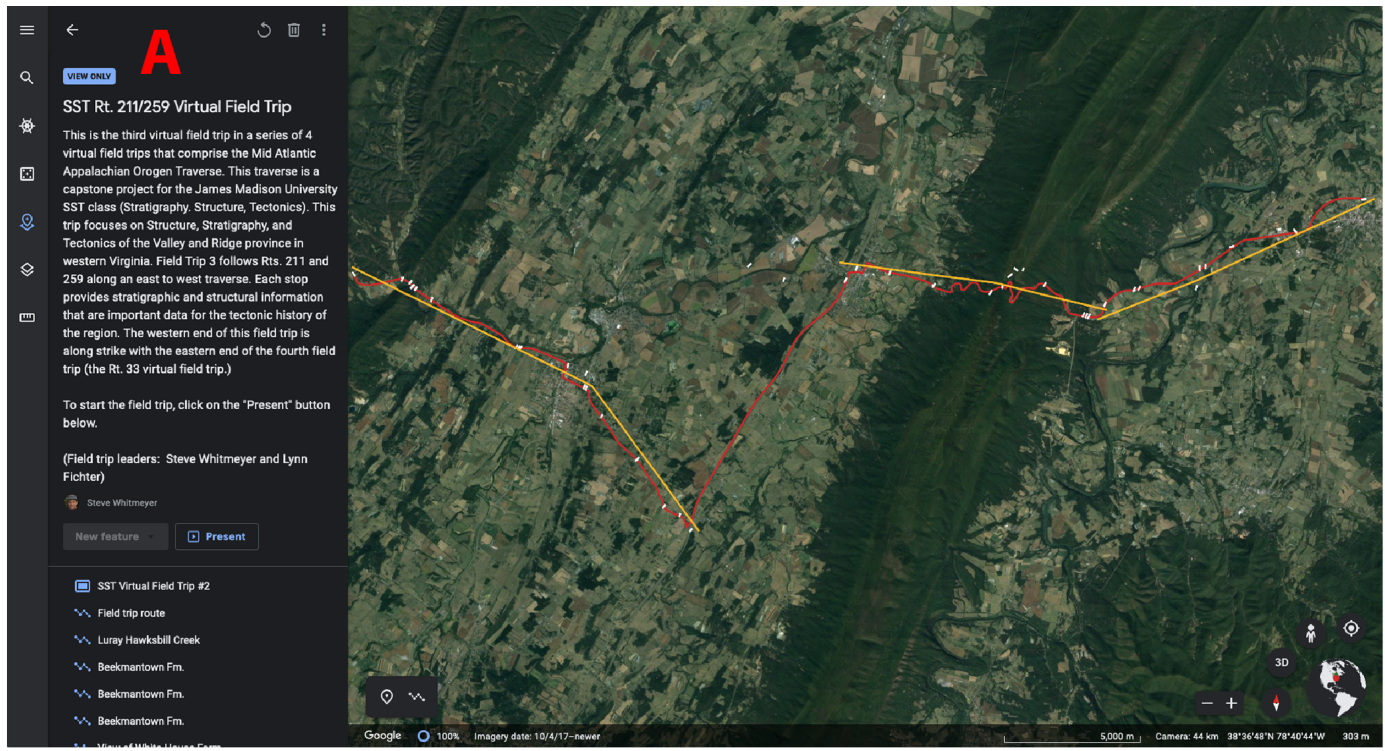

\section{${ }^{\circ}$ Rt. 211 - 259 Virtual Field}

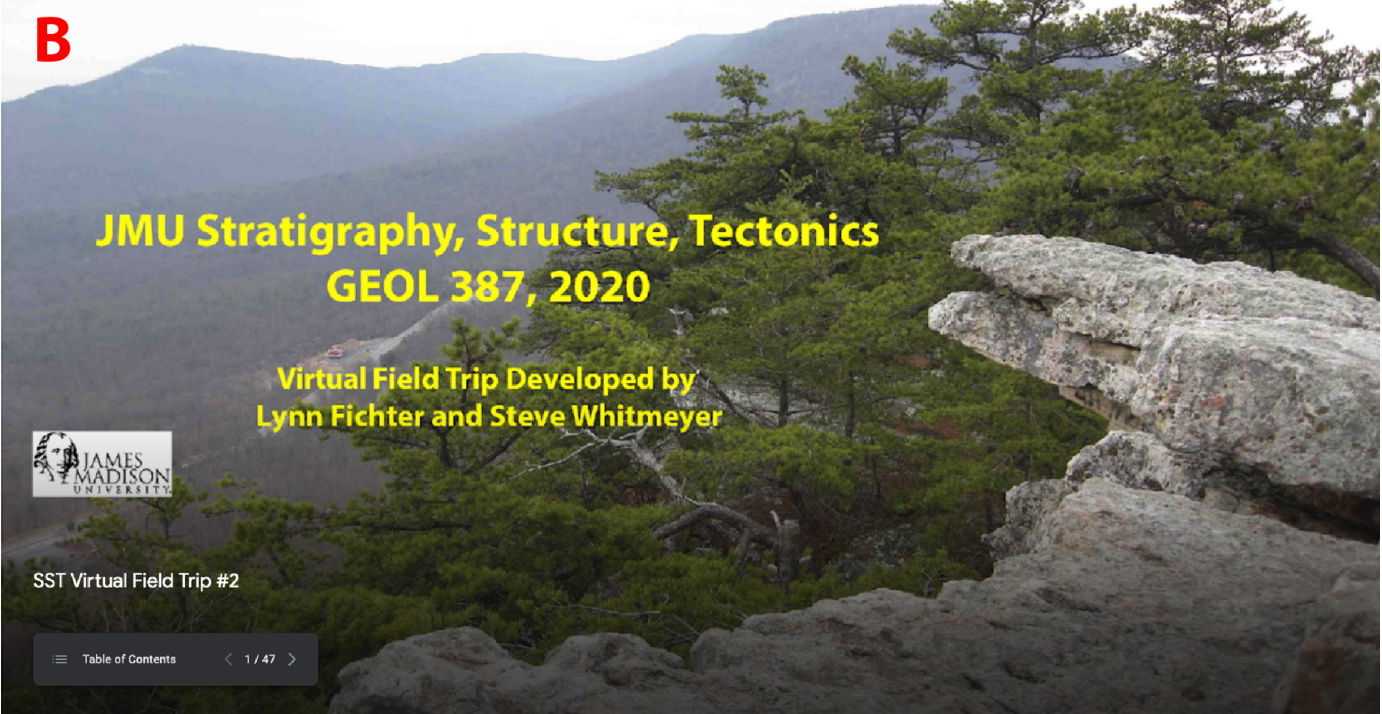

Figure 2. Screen images of web-based (C) Google Earth virtual field trip 3 from the Mid Atlantic Appalachian Orogen Traverse project; (a) overview of the SST Rt. 211/259 Virtual Field Trip project in (C) Google Earth; (b) title slide for the Rt. 211-259 Virtual Field Trip in (C) Google Earth.

al., 2019). In addition, aspects of community building and student integration into a community of practice can be lacking in virtual field experiences (Mogk and Goodwin, 2012; Race et al., 2021). However, Orion and Hofstein (1994) note the importance of limiting novelty space in field experiences, which can be somewhat addressed with virtual introductions to learning in the field. Considering these issues and challenges with online learning environments, SST instructors were mindful of the need to incorporate community building activities, include real-time observation and discussion of geologic features, and limit aspects of unidirectional content delivery.

\subsection{Instructor experiences with virtual field trips}

With the change to virtual interactions with students, instructional approaches to field-based teaching and learning were re-conceptualized, starting with development of the virtual field experiences. Experienced field instructors are aware that field work has its own methods and procedures, very different from the classroom (Whitmeyer et al., 2009; Mogk and 

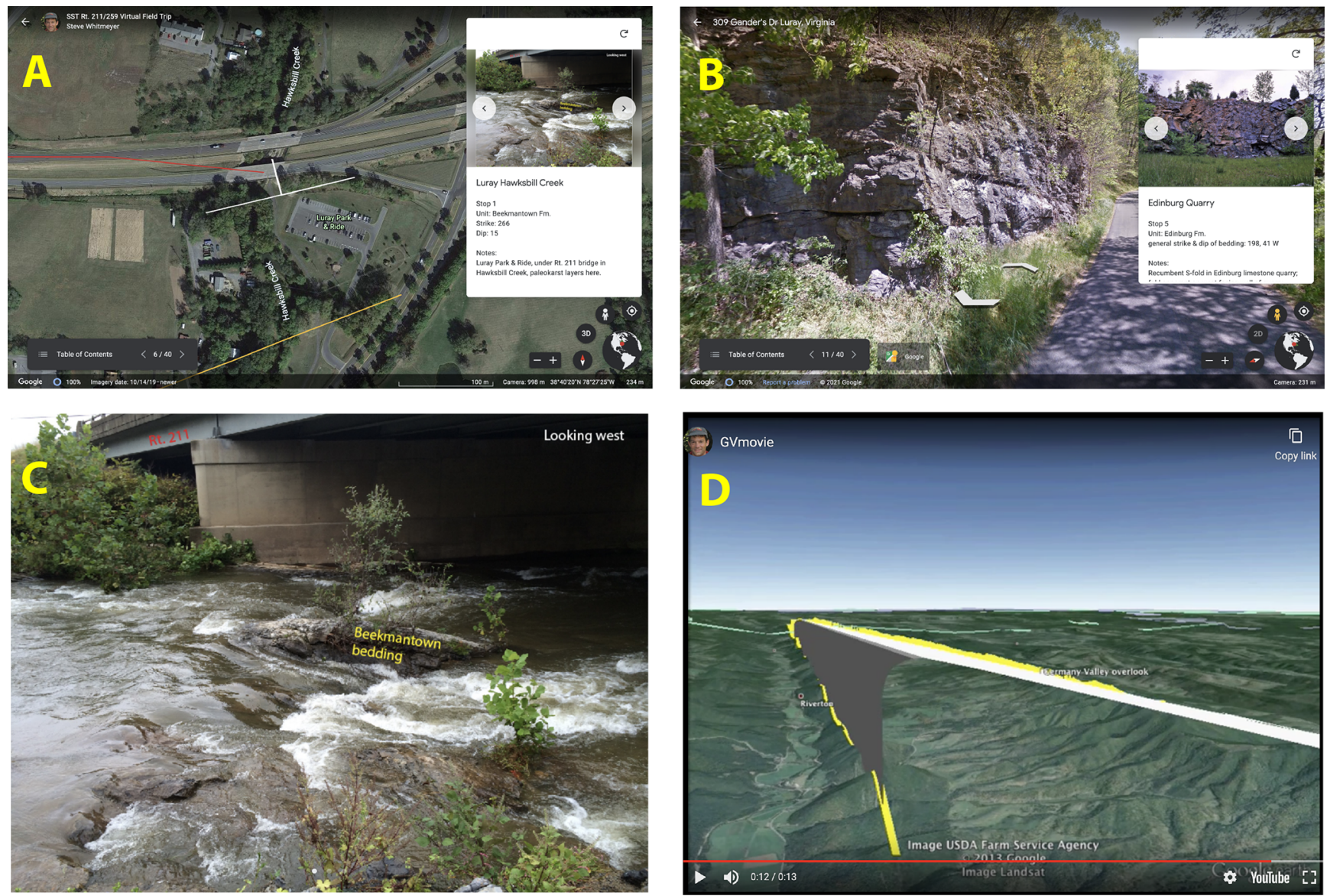

Figure 3. Screen images from web-based (c) Google Earth virtual field trips from the Mid Atlantic Appalachian Orogen Traverse project; (a) a virtual field trip site that shows a bird's-eye view of the outcrop location with an oriented strike and dip symbol drawn as a polyline in (C) Google Earth and a pop-up box with outcrop information and slide carousel; (b) a virtual field trip site that shows a zoomable and rotatable Street View image of the outcrop; (c) an annotated photo of a field site, shown as an enlarged image from the (C) Google Earth slide carousel from (a); (d) a model of a regional anticline displayed as a pop-up YouTube movie from the () Google Earth slide carousel.

Goodwin, 2012). For virtual field trips the challenge was to create an interactive learning experience for students within a virtual format with which they are less familiar. The process of redesigning field trips for a virtual environment started with instructors revisiting outcrops and systematically and deliberately considering the typical sequence of events, from exiting the vans, to investigating and discussing the outcrop features, to returning to the vans. Several months of development were necessary to create the MAAOT virtual field trips in web GE (as documented in Whitmeyer and Dordevic, 2021) and assemble associated supplemental materials. Fortunately, the instructors had collected field photos and videos from several years of visiting the field trip locations with previous SST classes, and many of these visual materials were included in the GE field trips. Similarly, supporting diagrams and models had been developed in previous years and were included with the virtual field modules as supplementary PowerPoint and PDF files.
Examination of an outcrop on an SST field trip starts with the outcrop's location and where it is situated within the regional geographic context. Constructing tectonic interpretations requires data from many outcrops across a wide region, and thus it is important for students to know the spatial relationships between the outcrops. Driving from stop to stop in the course of an on-location field trip can help illustrate the distances between outcrops. However, spatial relationships still can be a challenge, as many students travel from stop to stop without keeping track of their geographic locations. The GE component of a virtual field experience makes it easy to show the location of an outcrop within a broader region, which helps students conceptualize the regional geologic context.

Educational field experiences typically highlight hands-on observations, measurements, and field-based interpretations. An important component of observations at a real or virtual outcrop is recognizing and separating out stratigraphic vs. structural features, metamorphic overprinting, weather- 
ing phenomena, etc. (Compton, 1985; Coe, 2010). Each of these is an important outcrop datum, but the initial parsing of these features is an important component of SST. Outcrops are not always examined and discussed with the same hierarchy or order of investigations; sometimes structural analyses come first, and sometimes stratigraphic features are emphasized. Instructors in field settings have found it effective to ground their instructional approach in iterative cycles of encouraging observation, followed by interpretation, followed by subsequent rounds of more detailed observations and interpretations (e.g., De Paor and Whitmeyer, 2009; Mogk and Goodwin, 2012). Only after students have repeatedly been encouraged to get as much information from each outcrop as possible are they tasked with making bigger-picture synthetic observations and interpretations.

One of the challenges of virtual field trips is that what should be student inquiry-centered "observe and discuss" interactions can easily become unidirectional "show and tell" lecturing by field trip leaders. Without the ability to easily read faces or body language, observe students working the outcrop, or hold impromptu discussions, it is easy for instructors and students to become disconnected from what is ideally an interactive field experience (e.g., Petcovic et al., 2014). Recognizing the ease with which they could lapse into show and tell mode (e.g., online classroom lectures via Zoom), the SST instructors deliberately encouraged interactive discourse among participants at each field site and depended on a willingness from participants to highlight when virtual interactions and active participation were lacking. Taking the time to initiate discussions is important, and the key is to keep interactive conversations going throughout a field trip. As a field day progresses students generally get more comfortable with the discourse, as long as an interactive discussion framework is initiated early in the trip.

\subsection{Structural analyses on virtual field trips}

Structural analyses on SST field trips initially focus on characterizing lithologies and recognizing where in the stratigraphic sequence an outcrop is positioned, in addition to knowing where the outcrop is located geographically. Secondly, students need to record the orientations of planar fabrics, such as bedding or foliation, and recognize broad fold patterns and geometries from changing dip amounts and alternating dip directions. Thirdly, lineations and other outcrop-scale deformation fabrics (e.g., slickenlines, asymmetric porphyroclasts) are important to recognize and measure, where apparent.

The virtual field environment presents several challenges for collecting structurally related outcrop information and data. Identification of rock types and differentiation of lithologic units can be difficult with static images. Replicating orientation measurements online is a significant challenge, although virtual compasses do exist as components of some virtual outcrop experiences (e.g., Masters et al., 2020), and some 3D terrain models can be used for virtual measurements (e.g., Cawood et al., 2017; Brush et al., 2018). Our approaches to virtual field trips centered on providing outcrop imagery at multiple scales and in different formats (e.g., static outcrop photos, dynamic Street View images; Fig. 4a), often with annotations to highlight important features (Fig. 4b). Instructors used this imagery during Zoom discussions to iteratively encourage students to make ever more detailed observations of an outcrop, making sure that students obtained the salient lithologic and structural information that would aid in their subsequent tectonic interpretations.

Outcrop orientation measurements can be extremely difficult to facilitate in a virtual environment, and the experience of using a virtual geologic compass is currently ineffectual with a web-based platform like Google Earth. Thus, the approach in the MAAOT field trips is to provide orientation data in the pop-up boxes associated with stops that featured bedding, foliation, and/or lineation information (e.g., the text in the pop-up boxes of Figs. 3a, b and 4a). This is clearly not the same pedagogical experience for students as using a physical geologic compass (e.g., Brunton Pocket Transit) to take their own measurements on an outcrop, but the instructors accepted that this was not a skill that could be effectively replicated virtually.

Key deformation fabrics that are visible on an outcrop can be highlighted virtually via images, and an advantage of the virtual environment is that photos can include annotations that explain the relevant structural interpretations of a particular feature. For example, ductilely deformed porphyroclasts that display asymmetry can be used to determine the direction of movement that occurred during a ductile fault (shear zone) (Passchier and Simpson, 1986). Annotations on an outcrop photo can clearly demonstrate to students the appropriate way to interpret these features, as with the complex sigma porphyroclast in Fig. 4c that displays a top-to-the-left sense of movement. In addition, virtual images and animations can illustrate or model structural features that are at a regional scale - much larger than can be viewed at a single outcrop (e.g., the kilometer-scale anticline modeled in Fig. 3d). Instructors often attempt to model these larger structures for students while on-location at a key outcrop using verbal descriptions or hand waving, but they lack the ability to figuratively "step back" and illustrate the bigger picture. The ability to take a regional view of large features, and if desired display a model of them, is a distinct advantage of the virtual environment.

\subsection{Stratigraphic analysis and basin evolution on virtual field trips}

Field-based stratigraphy and basin analysis require somewhat different approaches from the analysis of structural features. Unlike tectonic structures (folds, faults, slickenlines, etc.), which are often visible on an outcrop, tectonic basins 

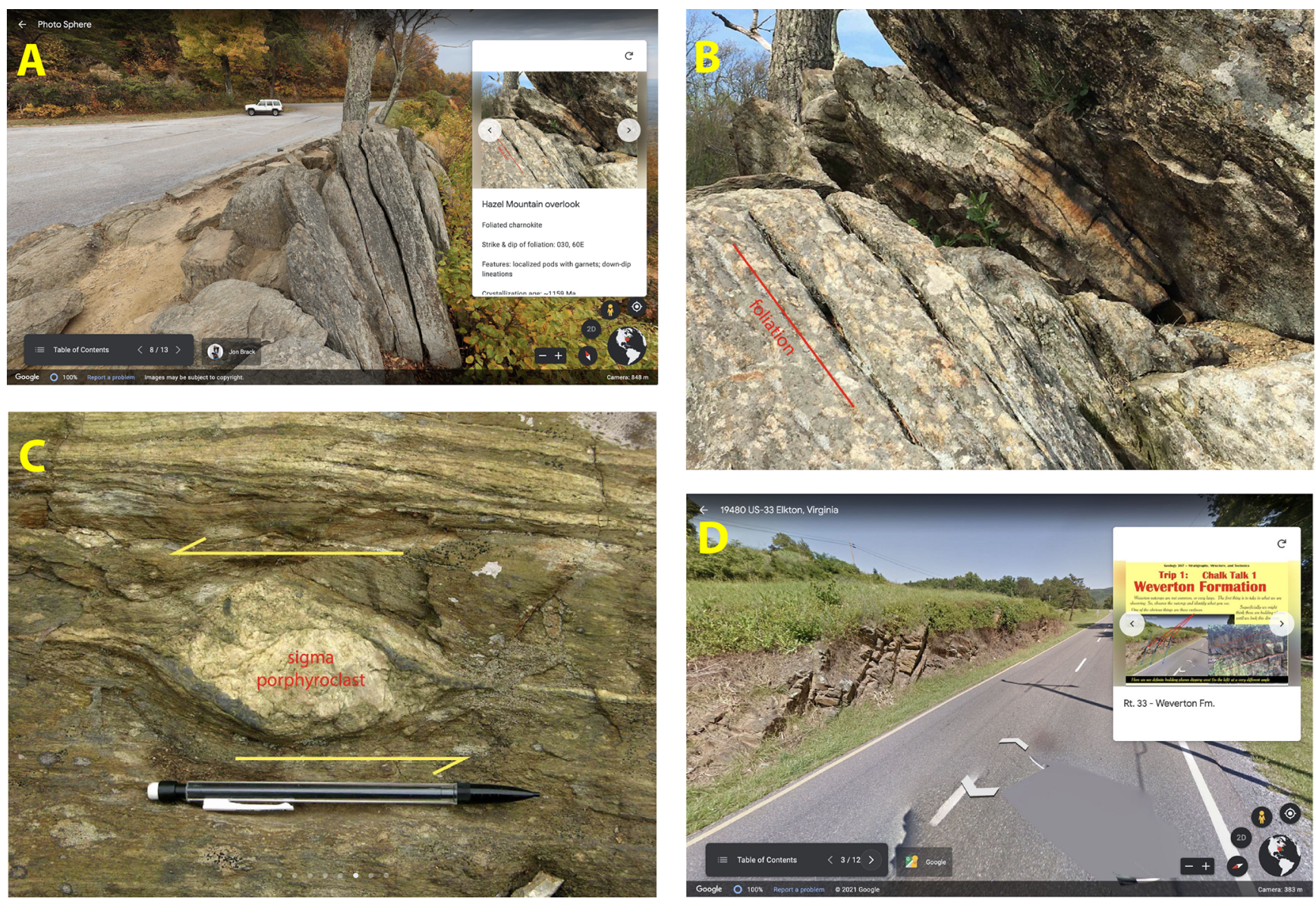

Figure 4. Screen images from web-based (C) Google Earth virtual field trips from the Mid Atlantic Appalachian Orogen Traverse project; (a) a Street View image of the Hazel Mtn. Overlook site from FT2, positioned to look along-strike of foliation; (b) an annotated photo of the same outcrop as (a), highlighting the foliation; (c) an annotated photo of a complex sigma porphyroclast from the Garth Run site of FT2; (d) a Street View image of the first field trip site of FT1 on Rt. 33 in western Virginia.

are at a scale that is not apparent at a single outcrop. In addition, depositional environments are interpretations built on a hierarchy of observations, which can be challenging to discern. The goals of field-based stratigraphy and basin analysis are to use bottom-up empirical data to construct a tectonic basin interpretation (e.g., Allen and Allen, 2005) and to use theoretical first principles and models to make interpretations of outcrop observations (e.g., Van Wagoner et al., 1990; Van Wagoner, 1995). The approaches to field-based stratigraphy and basin analysis in the SST course previously have been presented in detail (Fichter et al., 2010; Whitmeyer and Fichter, 2019). The paragraphs that follow highlight how these approaches have been adjusted and modified for the virtual environment.

Theoretical principles and models of stratigraphy, sedimentation, and basin analysis (e.g., Coe et al., 2003; Posamentier and Walker, 2006; Xie and Heller, 2009) are developed in SST classroom lectures and discussions, but commonly these topics have not been fully explored prior to the initial field trips in the MAAOT. In addition, the practical field skills of recognizing and identifying sedimentary structures (e.g., trough, planar, or hummocky cross stratification) and stratigraphic sequences (Bouma, hummocky, point bar, etc.) and drawing strip logs are best learned through practice. Concepts presented in the classroom are revisited and honed on the outcrop via iterative conversations. The main challenge in developing SST virtual field trips was to reproduce these experiences in Zoom, using GE-based presentations and PowerPoint chalk talks.

Stratigraphic analyses at an outcrop start with observation at a variety of scales, which can be facilitated by GE Street View imagery (Fig. 4d), such that students can virtually walk past an outcrop, zoom in and out, and view it from different angles. At a virtual field site, with or without Street View, this also necessitates student access to many detailed and annotated outcrop photos. In an on-location field trip this observation phase incorporates back and forth conversations between faculty and students, where faculty prompt students with questions and hypotheses that necessitate integration across scales of observation to build and refine a stratigraphic, basin 
analysis, and tectonic story. Initial overviews are followed by detailed investigations that use photographs of representative parts of an outcrop that include annotations to highlight bedding, sedimentary structures, textures, etc. However, it is challenging for students to learn to recognize stratigraphic features from a photograph. Thus, the resolution of the photos is important to ensure that the salient features are clear and unambiguous, which often necessitates multiple views of a feature. To facilitate this, the instructors revisited many MAAOT outcrops prior to the start of the Fall 2020 semester in order to get high-resolution pictures in the best lighting conditions and incorporate them into the GE field trip sites and supplementary documents.

An outcrop-oriented synthesis activity for students encompasses drawing a strip log, and in virtual environments this is accomplished by examining an outcrop photo or sequence of photos with a lengthy exposure. The activity commences with a discussion of the stratigraphic section under consideration (instructors obtained detailed images for this purpose), where students make preliminary observations and initiate a dialogue about what they observe. Students proceed to draw their own strip logs from a combination of what they have observed and information they have developed via the discussions. At this point during an on-location field trip students would lay their strip logs down on the ground for group examination that includes provocative discussion prompts from instructors. This can be challenging to accomplish virtually, although an approach used in SST was for students to hold their drawings up to their laptop or mobile device cameras for viewing by the group. Students then re-draft their strip logs, progressing through as many iterations as are necessary, in order to build observational and interpretive skills. This iterative approach can be time consuming on-location at an outcrop, where environmental factors can impact productivity and morale. A virtual setting facilitates an expanded timeframe for iterative discussions and analyses, which may prove more effective for student learning.

\subsection{Synthesis discussions on virtual field trips}

Outcrop investigations for both stratigraphic and structural datasets progress from observations through interpretations and culminate with tectonic syntheses, becoming progressively more theoretical in focus. In an on-location field trip theoretical interpretations are presented with posters ("chalk" boards) tacked to the sides of vans or as paper handouts. This can be problematic in bad weather or in a large class where students on the distant edges of the group have trouble seeing and hearing the discussions. Virtual chalk talks on Zoom using PowerPoint slides obviates this - everyone has the same access and opportunity to interact, without the distractions of environmental factors. Virtual chalk talks have the facility to display detailed models that were initially presented in classroom lectures to the relevant data that students just examined on the outcrop. In the classroom the theoretical models likely did not have much relevance to the students, but because the virtual chalk talks can incorporate high-quality illustrations for discussions at the virtual outcrop, learning can be timely and relevant. As stops accumulate throughout a field day the theoretical models keep reappearing and building on each other. Thus, the models and concepts become familiar and increasingly more relevant to the students, with the added cognitive stimulus provided by associating the theoretical models with tangible data from outcrops and sequences of field trip locations.

\section{Survey of student experiences with in-person vs. virtual educational formats}

Historically, the geosciences have been largely field-focused (e.g., Himus and Sweeting, 1955), and undergraduate curricula have traditionally incorporated a significant component of field-based learning (Whitmeyer et al., 2009; Mogk and Goodwin, 2012). This field emphasis has been used for many years to recruit students to the discipline that have an affinity for, and appreciation of, the outdoor environment. An ongoing challenge in geoscience disciplines is to increase access and inclusion for all students (Bernard and Cooperdock, 2018; Ali et al., 2021; among many others), yet field-based learning experiences can present a significant barrier to those efforts (e.g., Clancy et al., 2014; Giles et al., 2020). Disability access to field environments is a growing concern among geoscientists and geoscience departments (Carabajal et al., 2017; Whitmeyer et al., 2020), especially with regards to recruitment and retention of students in geoscience-related fields (Baber et al., 2010; LaDue and Pacheco, 2013; Stokes et al., 2015; Pickrell, 2020). Virtual field experiences are one potential solution to inaccessible field experiences, but few data exist on academic growth during virtual field experiences and how that growth compares to in-person field learning.

With these things in mind, an online survey was developed to collect data from undergraduate SST students on their perceptions of both virtual and online field experiences as well as self-evaluations of their academic growth in each of those environments. The survey was sent to SST students that had participated in the virtual field trips for the MAAOT in Fall 2020 as well as to SST students from the 5 previous years that had participated in traditional on-location field trips during the Fall semesters. The instructors for the SST course and field trips were the same across all years of the survey. The survey included questions that addressed student preferences for in-person or virtual field experiences, selfevaluations of academic growth across a range of topics relevant to the SST course, and questions that addressed student disabilities in the context of field access and inclusivity. Details of survey questions are available in the Supplement.

Data were collected anonymously via an online survey instrument using Survey123 through ArcGIS Online. In 


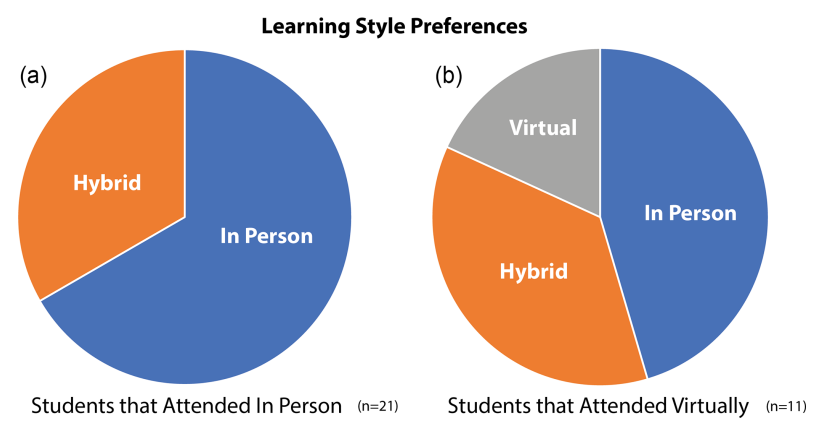

Figure 5. Charts of learning style preferences from student survey; (a) learning style preferences from students that attended SST classes and field trips in person, with no preferences for virtual learning style indicated; (b) learning style preferences from students that attended SST classes and field trips virtually, with a greater preference for hybrid and virtual learning styles.

accordance with guidelines from the Institutional Review Board (IRB) at JMU, survey data were anonymized to remove any information that could facilitate identification of individual respondents, and no demographic data were collected. All survey respondents had the option to disallow the use of their responses to any question in the survey. Survey data were aggregated across all responses or aggregated within two groups: students that participated in virtual field experiences and students that participated in on-location field experiences. These methodologies for data collection, analysis, and reporting are in accordance with the ethical policies at JMU, and the methods were approved by JMU's IRB. Responses to the survey were received from 11 students that participated in virtual field experiences in the Fall 2020 semester and 21 students that participated in on-location field trips from the SST course across 5 previous years. The responses were organized into three themes: preferences for in-person vs. virtual field experiences, disability and field access, and a comparison of academic growth between inperson and virtual field learning.

\subsection{Student preferences for virtual vs. in-person learning experiences}

Prior to Fall 2020, the lectures, labs, and field trips in the SST course were all conducted in-person and on-location in the field. None of the students that took SST prior to Fall 2020 had experience with virtual classes or virtual field trips, outside of the occasional use of a virtual platform like Google Earth to illustrate regional to global-scale topographic or geologic phenomena. Not surprisingly, students that took the SST course prior to 2020 did not indicate a preference for virtual learning, although a few students recognized the potential value of hybrid experiences that combined both virtual and on-location field learning (Fig. 5a).

Some students that experienced virtual learning and virtual field experiences in the Fall 2020 SST course likewise

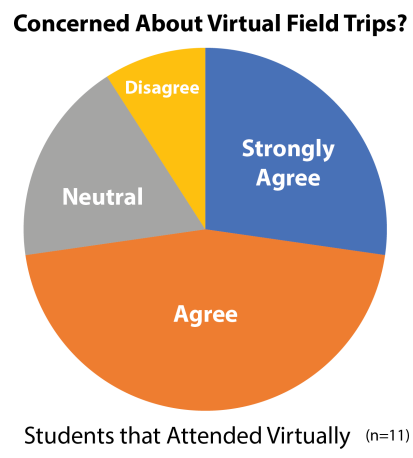

Figure 6. Chart of responses from students that attended SST virtually on whether they were concerned about participating in field trips virtually.

indicated a preference for in-person experiences; however, a majority of these students indicated a preference for hybrid or virtual learning experiences (Fig. 5b). In addition, most of the Fall 2020 students that attended SST as a virtual class indicated that they had some concerns about virtual field trips prior to experiencing them (Fig. 6). However, Fig. 5b suggests that many of these students gained an appreciation for virtual field experiences by the end of the course.

For many students virtual field experiences were not as satisfying as being physically at an outcrop, as noted in the following response from a student that attended SST virtually:

While I feel as though I have missed out on an important [field] experience by taking SST online...

However, that response continues with

... I feel I learned more than I would have because of my ability to re-watch lectures and go back to the [virtual] field trips.

This response is representative of several student responses that noted the advantage of reviewing and revisiting virtual field trips and field sites after an initial experience. This includes several students that attended on-location field trips, who indicated a curiosity about, and an awareness of, the potential for virtual field experiences. Some examples of these responses include the following:

I took all in-person geology courses prior to graduating, so I was never given the option to take any field trips virtually, but I wish I could have seen how they may have worked, and what software was used.

The virtual field trips in google earth are very well done and I think those things are helpful.

... I have never attended an online field trip, so

I am unfamiliar with them. It would be nice to 
Table 1. Responses from the student survey that discuss disability access and inclusion issues for field trips. Responses are grouped according to modality of learning environment (in-person or virtual.)

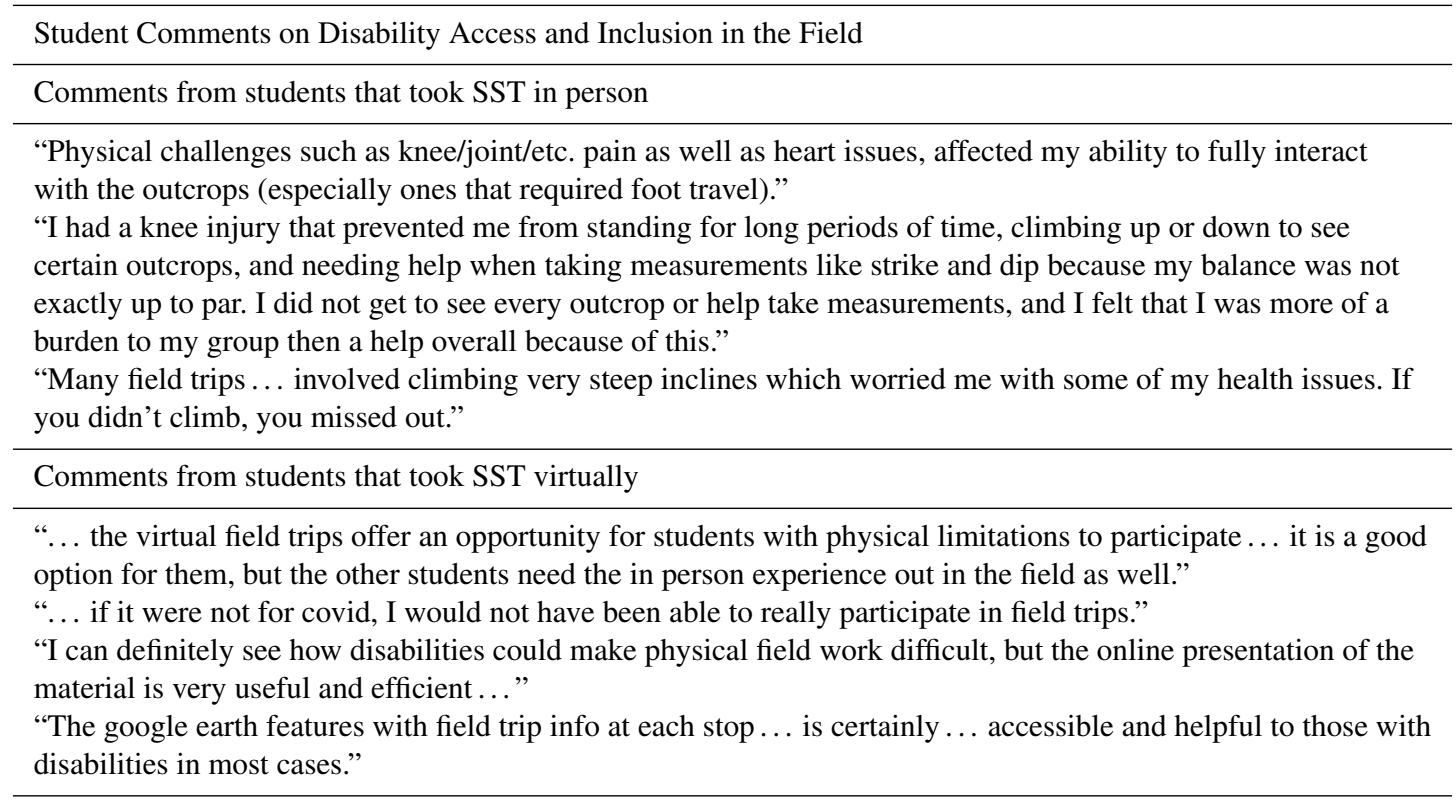

have the opportunity to catch anything I might have missed during field trips [due to] loud cars, not [standing] close enough to the speaker, or having to sit out on a few steep outcrops.

The response above also highlights the inclusivity of virtual field experiences, where every student has an equal opportunity to examine and investigate each outcrop and participate with other students and instructors, regardless of physical ability or proximity to ongoing discussions. Accessibility aspects of virtual field experiences are discussed in more detail in the section that follows.

\subsection{Student views on disabilities and field access}

Survey results indicate that a majority of SST students agreed that students with disabilities may be deterred from majoring in the geosciences due to the expectation that fieldwork is a necessary component of upper-level courses (Fig. 7). Many SST students, across both learning modalities (in-person and virtual), indicated an awareness of challenges and issues associated with disability access in field settings. As one student noted,

... the geosciences in general have a stereotype of being the science of the rugged outdoorsman, and that deters people with disabilities.

Table 1 contains narrative responses from the student survey that reflect disability access and inclusion issues for field trips, including those in the SST course. Several SST students dealt with accessibility challenges during the on-location field trips and indicated that they would have welcomed the

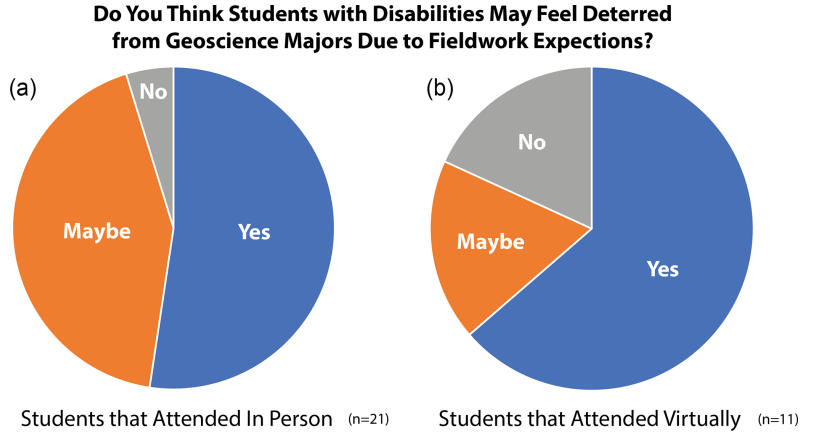

Figure 7. Responses from students of both in-person and virtual modalities on whether they thought students are discouraged from majoring in the geosciences due to a fieldwork requirement in undergraduate curricula.

option of viewing and investigating outcrops virtually. Students that participated in virtual field trips also indicated an awareness of field access issues for students with disabilities, as highlighted in the last few responses in Table 1. Regardless of whether students had experience with virtual field trips, there was recognition that issues like navigating topographic relief to see outcrops close-up or just getting in and out of vans multiple times during a trip presented challenges for some students. Virtual field experiences were seen as a viable alternative by many students, regardless of whether they had experience with virtual modalities.

Student responses also highlighted the potential for technological solutions to augment field experiences. Some students were made aware of the potential for mobile commu- 
nications devices to augment field experiences for disabled students via a student presentation that highlighted ongoing research (Atchison et al., 2019; Whitmeyer et al., 2020). The responses below were from students that attended SST inperson but recognized the potential of technology for improving field access:

I saw the use of ipads and video chats to help those with physical disabilities that may not be able to visit certain onsite locations.

... the student had tested a novel system for broadcasting outcrops which were inaccessible to students with disabilities through livestreaming on an ipad or similar technology. Seemed like it had a lot of potential!

These responses highlight the possibilities for enhancing accessibility in the field and suggest ways for improving inclusivity for SST and other geoscience courses, as a hybrid approach to virtual and in-person learning.

\subsection{Student perception of academic growth during the SST course}

Students were asked to self-evaluate their academic growth from the beginning to the end of the course. The survey instrument used a scale of 1 (little academic growth) to 10 (most academic growth possible) to facilitate evaluation of overall academic growth during the semester as well as growth in key topics in the general areas of stratigraphy, structure, and tectonics (Table 2).

In all categories students that took the course in person reported higher mean scores than students that took the course virtually. In general, stratigraphy topics displayed a greater discrepancy in mean responses between students that attended in person and students that attended virtually. However, the topical categories that show the greatest discrepancies between in-person and virtual attendance encompass all three general areas: strip logs (deviation of 1.63; stratigraphy), cross sections (deviation of 1.32; structure), and the Wilson Cycle (deviation of 1.22; tectonics). It is worth considering that these three categories represent topics that require synthesis of data in the preparation of summary diagrams, interpretations, or models. This disparity between modes of attendance in students' perceptions of their abilities to synthesize data may also be reflected in the relatively significant discrepancy (0.93) in their evaluations of their overall academic growth during the semester.

Student perceptions of their academic growth during the SST course reflected classroom, laboratory, and field learning environments. Thus, the deviations between the higher self-reporting scores for students with in-person attendance and the lower scores for virtual attendance do not only reflect on-location vs. virtual field experiences. However, several topics that directly address field-oriented learning (constructing strip logs, ability to apply the geologic timescale on field trips, interpreting cross sections and identification of geologic structures, understanding tectonic events through time) indicate that students that participated in virtual field experiences were generally less confident of their academic growth in field-focused learning than students that participated in on-location field trips. Several factors likely contributed to this result.

First, the SST instructors have many years of experience with on-location field trips and have fine-tuned the MAAOT trips over the course of several years to maximize the student experience. In contrast, Fall 2020 was the first semester in which the field experiences were fully virtual, and it is likely that the student learning environment was less effective and less positive as a result. Many SST students seem to look forward to the field trips as highlights of the course, and in 2020 many students expressed disappointment or even apprehension (e.g., Fig. 6) that the field trips would have to switch to virtual delivery and participation. These apprehensions are highlighted in some qualitative responses to the student survey; for example,

As someone who would not consider themselves to have a severe disability, [the SST course] still took a huge toll on me both physically and mentally.

We are told that a geologist is only as good a geologist as the amount of geology they see and a lot of people with disabilities can't see all of the things able-bodied people can.

Reduced enthusiasm for the virtual field component of the course may have resulted in less effort by the students. However, apprehension for on-location field trips on the part of students with mobility challenges or other environmental concerns may have been alleviated once students gained experience with virtual field trips. In addition, it is likely that the general frustrations of both faculty and students with the restrictions imposed by the COVID pandemic had negative effects on the academic learning environment as well as on general living conditions. These effects are hard to quantify but were certainly experienced by the authors and expressed to them by many students during the Fall 2020 and subsequent semesters that were impacted by the pandemic.

\section{Discussion}

Many of the challenges faced by instructors with the switch to virtual field experiences revolved around determining the most effective ways to accomplish traditional field learning goals (e.g., Mogk and Goodwin, 2012; Petcovic et al., 2014) within a less familiar virtual environment. Engaging students in a dialogue can be challenging in a virtual environment where students may or may not have web-linked video cameras turned on and may have other distractions going on concurrently in their home environments. Asking students to focus on virtual images of outcrops to discern salient 
Table 2. Student survey responses highlighting self-evaluation of academic growth from the beginning to the end of the Stratigraphy, Structure, Tectonics (SST) course. Responses are grouped by whether the students took the course in person $(n=21)$ or virtually $(n=11)$. Key topics highlighted include those with a stratigraphic focus $(\mathrm{a}-\mathrm{c})$, those with a structural focus ( $\mathrm{d}$ and e), and those with a tectonics focus (f-h). Academic growth is reported on a scale of $1-10$, where $1=$ little academic growth and $10=$ the most academic growth possible; means of responses and ranges of responses are indicated.

\begin{tabular}{|c|c|c|c|c|c|}
\hline \multicolumn{6}{|c|}{ Academic growth in key topics of Stratigraphy, Structure, Tectonics (SST) course } \\
\hline \multirow[t]{2}{*}{ Topic } & \multicolumn{2}{|c|}{$\begin{array}{l}\text { Students that took the } \\
\text { course in person }\end{array}$} & \multicolumn{2}{|c|}{$\begin{array}{l}\text { Students that took the } \\
\text { course virtually }\end{array}$} & \multirow{2}{*}{$\begin{array}{l}\text { Discrepancy } \\
\text { in means } \\
\text { of responses }\end{array}$} \\
\hline & $\begin{array}{l}\text { Mean of } \\
\text { responses }\end{array}$ & $\begin{array}{l}\text { Range of } \\
\text { responses }\end{array}$ & $\begin{array}{l}\text { Mean of } \\
\text { responses }\end{array}$ & $\begin{array}{l}\text { Range of } \\
\text { responses }\end{array}$ & \\
\hline $\begin{array}{l}\text { a. Identifying and } \\
\text { understanding } \\
\text { depositional } \\
\text { environments }\end{array}$ & 6.90 & $3-10$ & 6.18 & $2-10$ & 0.72 \\
\hline $\begin{array}{l}\text { b. Constructing strip } \\
\operatorname{logs}\end{array}$ & 6.90 & $3-10$ & 5.27 & $1-9$ & 1.63 \\
\hline $\begin{array}{l}\text { c. Ability to apply the } \\
\text { geologic timescale on } \\
\text { field trips }\end{array}$ & 7.43 & $4-10$ & 6.82 & $3-9$ & 0.61 \\
\hline $\begin{array}{l}\text { d. Interpreting cross } \\
\text { sections and } \\
\text { identification of } \\
\text { geologic structures }\end{array}$ & 8.05 & $5-10$ & 6.73 & $3-9$ & 1.32 \\
\hline $\begin{array}{l}\text { e. Evaluating } \\
\text { structural concepts } \\
\text { and deformation }\end{array}$ & 7.14 & $2-10$ & 7.09 & $4-10$ & 0.05 \\
\hline $\begin{array}{l}\text { f. Tectonic } \\
\text { interpretations of } \\
\text { rocks and minerals }\end{array}$ & 6.43 & $3-9$ & 6.09 & 4-9 & 0.34 \\
\hline $\begin{array}{l}\text { g. Interpreting and } \\
\text { applying the Wilson } \\
\text { Cycle }\end{array}$ & 6.95 & $3-10$ & 5.73 & $2-10$ & 1.22 \\
\hline $\begin{array}{l}\text { h. Understanding } \\
\text { tectonic events } \\
\text { through time }\end{array}$ & 7.29 & $3-10$ & 7.00 & 4-9 & 0.29 \\
\hline $\begin{array}{l}\text { Overall academic } \\
\text { growth }\end{array}$ & 7.57 & $5-10$ & 6.64 & $3-8$ & 0.93 \\
\hline
\end{tabular}

features is not the same as tactile investigations of an outcrop in the field. Important outcrop details usually need to be highlighted in an image through annotations (e.g., Figs. 3c and $4 \mathrm{~b}$ ) or explained in a video. This is not the same experience as directing students to examine an outcrop to find these features for themselves. However, if an effective dialogue can be established between students and instructors in the virtual environment, many of the same interpretation and synthesis goals can be achieved through probing questions and repeated directed observations. One advantage of virtual field trips is that supporting diagrams, models, and other materials are immediately at hand and can be easily displayed (e.g., Fig. 3d) and annotated in real time by instructors and students. Similarly, process-based models that sequentially change through time can be easily displayed virtually, which would be more challenging to show and discuss on location in the field. These and other relative advantages and disadvantages of virtual field experiences vs. on-location field trips are discussed in more detail below. 


\subsection{Pedagogical advantages and disadvantages of virtual vs. on-location field experiences}

On-location field experiences have been the traditional format for field-based education for many years, and virtual field experiences are typically evaluated in comparison to onlocation trips. If the statement attributed to Herbert Harold Read that "The best geologist is the one that has seen the most rocks." (Young, 2003, p. 50) has merit, then virtual field experiences would seem to have inherent weaknesses that could be challenging to overcome, some of which are readily apparent, such as the following points.

1. The tactile components of on-the-outcrop investigations: on virtual field trips students do not experience their own self-directed examinations of the rocks (minerals, fabrics, structures), which can inhibit observationally grounded geologic interpretations. Field skills, such as using a hand lens for detailed observations or taking outcrop measurements with a geologic compass, are not effective in a virtual environment, and thus students do not have the opportunity to practice and refine these field-oriented skills. In addition, recollection of the geologic features of an outcrop can also be enhanced by tactile experiences.

2. A clear appreciation of the spatial dimensions of the region and the relative locations of outcrops: virtual experiences via Google Earth are effective in showing bird'seye or regional views of a field trip area, but the actual separation and distance between each outcrop is more easily grasped when physically traveling from location to location on the ground, whether walking or driving.

3. Learning safety in the field: during on-location field trips instructors spend significant time and effort highlighting outcrop safety. MAAOT field trips incorporate many outcrops that are roadcuts along busy highways, and many of these outcrops are steep or subvertical and tower above the students. Throughout an on-location field trip, participants are encouraged to wear reflective vests, and instructors are constantly yelling "Rock!" or "Car!" to encourage safety on the outcrop; this sense of awareness of one's surroundings and physical environment cannot be experienced virtually.

4. A sense of appreciation and enthusiasm for the natural world: historically, one of the drivers for recruitment in the geological sciences is the sense of wonder and excitement that students obtain from being physically present in awe-inspiring natural settings (e.g., Carson, 1965; Petcovic et al., 2014). This emotional connection with the real world is not present in virtual electronic environments.

However, virtual field trips offer some distinct advantages, as highlighted below with reference to the MAAOT field trips.
On virtual field trips it is not necessary to visit outcrops in the order dictated by geography and the local road network. In the region of the MAAOT it is possible to visit many formations in stratigraphic order, but that is not always the case in other regions. In areas where outcrops are not chronologically sequenced, field locations can be mixed and matched, using Google Earth to keep students geographically oriented.

On an on-location field trip each outcrop has to be examined for every piece of stratigraphic, structural, and tectonic evidence while at the outcrop. This tends to make field notes complex and chronologically disjointed and can break up the rhythm of interpretations. On a virtual field trip a series of outcrops can be visited to understand the structural details, then revisited to focus on stratigraphic details, and then revisited again for basin analysis and tectonics. It can take more time, but this approach can facilitate better organization of the information by students.

An on-location field trip cannot easily incorporate observations from related but distant outcrops of the same formation that illustrate variability or regional facies changes. On a virtual trip, stops at different locations that feature the same rock unit can be visited sequentially as a group to cohesively present the data available and investigate changes across distances.

Because the MAAOT virtual field trips incorporate PowerPoint supplemental files it is possible to include many images that might not be easy to examine on location at an outcrop. For example, environmental interpretations of the Juniata and Tuscarora formations (Field trips 3 and 4) can be facilitated and enhanced by using pictures of contemporary tidal flats and beach/barrier island systems. Or, for the Acadian Catskill clastic wedge, atmospheric circulation models and paleo positions, as well as paleontological evidence, can be helpful for reconstructing possible environmental conditions during deposition.

In virtual field trips, all of the students get the same amount of time and opportunities to examine an outcrop. In contrast, with large classes and small outcrops, in on-location field trips instructors cannot be sure that everyone has had ample time on the outcrop to see all of the salient details. Similarly, students may not have had equal opportunities to discuss the outcrop with the instructors. In addition, some outcrops are physically challenging to get to (e.g., the necessity of climbing steep or unstable slopes to see an outcrop). With virtual field trips all students have equal access to an outcrop.

Students can easily revisit virtual field trips and field locations for quick reminders and reviews, as long as the virtual field trip files are made available during and after the instructor-led field trips. This can be an effective mechanism for student teams to revisit MAAOT field trip sites while they are working on their cross section interpretations and synthesis reports.

The GE virtual format provides the opportunity to take field trips to distant locations that might not otherwise be feasible or practical for on-location field trips. As the library 
of high-quality virtual field trips accumulates (e.g., NAGT's Teaching with Online Field Experiences site), it will be possible to take students on field trips to many places in the world that otherwise might not be accessible.

\subsection{Student perceptions of hybrid field experiences}

Survey results indicate that students that took SST in person generally were unaware of virtual field experiences. For students steeped in the tradition of observing and interpreting geology in the field, it is not surprising that they did not envision options for virtual or remote field experiences. However, while several student responses from the survey highlighted the perceived importance of on-location field trips, other comments recognized the potential for a hybrid approach that incorporated both on-location and virtual features. Survey responses from students that noted specific benefits to a combined hybrid approach are highlighted below.

1. Field accessibility

Offering more virtual options to students in the future, even if most of the class chooses to do in-person versions. I think most students, like myself, prefer in-person field trips, but I can see how it may be hard for some students to do that.

For outcrops that I was (and other individuals were) unable to traverse to/focus on, incorporating a 'virtual' aspect, similar to what's being offered now, would've been useful to allow us to see the outcrop without having to forgo the experience/knowledge.

2. Revisiting field sites:

... a virtual option for outcrops,... where I would be able to catch up on the material I was unable to [see], would be vastly useful.

Having a resource of a digital version of the [field] trip, with some key photos and points of the stop to assist in aligning personal notes with the stops would have been a helpful reenforcer.

3. Incorporating modern mobile technologies to enhance inclusivity

Virtual field trips in addition to physical/inperson ones - i.e., having someone with a cellular-enabled iPad come along on the field trips to stream video back to anyone who didn't/couldn't join.

4. Using virtual field experiences in combination with onlocation field trips
Using Google Earth to conduct virtual field trips was difficult and not the same as an in-person field trip but combining the use of Google Earth with in-person trips may be beneficial.

I think some of the resources we used in online learning were extremely helpful, such as the Google Earth stops and the images of the outcrops in better conditions. I don't think they substitute for the in-person experience, but if field trips might become a mix of inperson observation and data collection plus recorded/online chalk talks, it might be beneficial.

\subsection{Future impacts of virtual field experiences}

With the Fall 2021 transition back to an environment where on-location field trips are once again possible, SST instructors are using the MAAOT virtual field experiences to augment the five on-location field trips. In general, students were eager to return to the tactile, on-the-outcrop experience of onlocation field trips. However, they also appreciated the added perspectives of the virtual field experiences to enhance the learning and review process. For the SST instructors, experiences and insights derived from running MAAOT field trips virtually in Fall 2020 impacted how on-location field trips were conducted in Fall 2021. Instructors noted two key components of virtual trips that could enhance on-location field experiences, specifically (1) the ability to incorporate outcrop examples from locations that could not be visited in person and (2) the ability to conduct synthesis discussions that incorporated outcrop data and interpretations from multiple locations. For the Fall 2021 on-location field trips the instructors prepared posters that synthesized data and theoretical models from the VFE PowerPoint chalk talks and displayed these on the sides of vans to augment in-depth discussions at key outcrops. These posters also helped with bundling outcrop observations and interpretations across several field sites in order to discuss and interpret geologic features that evolved across a regional scale. The instructors envision that other aspects of the VFEs will be incorporated into future on-location field trips. Ultimately, the authors view a hybrid field experience that incorporates features of both virtual and on-location field trips as a more inclusive approach to field-based learning and a richer pedagogical experience for all students.

\section{Conclusions}

Virtual learning, whether in the classroom, lab, or the field, may not be an appealing or effective solution for all students. Interestingly, students that attended SST in-person were more supportive of virtual learning options, perhaps reflecting a desire that these options had been available when 
they took the course. A key consideration is that some traditional on-location field experiences can be challenging for students with physical and other disabilities, and geoscience departments need to have alternatives in order to accommodate all current and prospective students. For future students that may be unable to visit certain outcrops, a virtual field experience will provide them with a way to investigate an outcrop and participate with other students in a meaningful and knowledgeable way. This is not only an ethical consideration but also important from a recruitment perspective, where geoscience educators need to welcome students from all backgrounds in order to ensure the continued health of the discipline.

Another consideration is the continuing uncertainty of the COVID pandemic situation and the possible impacts of future variants. Throughout the Fall 2021 semester we unfortunately are witnessing repetitive surges of COVID cases, underscoring the potential for restrictions to travel and field access at some point in the future. With the development of virtual field experiences, such as those included in the MAAOT project, instructors have alternative options if on-location access to field sites is restricted. The necessity of virtual field options has always existed for some geoscience students, but the COVID pandemic has made all of us realize that these virtual options need to be available to the full community of students and instructors.

Data availability. All data and datasets that are relevant to this research are included as tables or as links to websites if the data are web based. There are no other data to include.

Supplement. The supplement related to this article is available online at: https://doi.org/10.5194/se-12-2803-2021-supplement.

Author contributions. All authors contributed to the writing of the paper. HL drafted and administered the student survey and collected the student data.

Competing interests. The contact author has declared that neither they nor their co-authors have any competing interests.

Disclaimer. Publisher's note: Copernicus Publications remains neutral with regard to jurisdictional claims in published maps and institutional affiliations.

Special issue statement. This article is part of the special issue "Virtual geoscience education resources". It is not associated with a conference.
Acknowledgements. The authors want to thank all of the SST students over the years that have participated in MAAOT field trips and provided their thoughts and perspectives on the project. Particular thanks go to the 32 students that responded to our online survey. Steven Whitmeyer also acknowledges the inspiration of Declan De Paor, who realized the potential for Google Earth-based virtual field experiences many years ago - "nanos gigantium humeris insidentes". The authors appreciate reviews from Terry Pavlis and an anonymous reviewer that have helped to improve this paper.

Review statement. This paper was edited by Marlene Villeneuve and reviewed by Terry Pavlis and one anonymous referee.

\section{References}

Ali, H. N., Sheffield, S. L., Bauer, J. E., Caballero-Gill, R. P., Gasparini, N. M., Libarkin, J., Gonzales, K. K., Willenbring, J., Amir-Lin, E., Cisneros, J., Desai, D., Erwin, M., Gallant, E., Gomez, K. J., Keisling, B. A., Mahon, R., Marin-Spiotta, E., Welcome, L., and Schneider, B.: An actionable anti-racism plan for geoscience organizations, Nat. Commun., 12, 3794, https://doi.org/10.1038/s41467-021-23936-w, 2021.

Allen, P. A. and Allen, J. R.: Basin analysis: Principles and applications, Oxford, Blackwell Sci. Pub., p. 549, ISBN 978-0-47067377-5, 2005.

Anderson, L. W., Krathwohl, D. R., Airasian, P. W., Cruikshank, K. A., Mayer, R. E., Pintrich, P. R., Raths, J., and Wittrock, M. C.: A taxonomy for learning, teaching, and assessing: A revision of Bloom's Taxonomy of Educational Objectives (Complete edition), Longman, New York, 2001.

Atchison, C., Parker, W., Riggs, N., Semken, S., and Whitmeyer, S.: Accessibility and inclusion in the field: A field guide for central Arizona and Petrified Forest National Park, in: Geologic Excursions in Southwestern North America, GSA Field Guide 55, edited by: Pearthree, P. A., 39-60, https://doi.org/10.1130/2019.0055(02), 2019.

Baber, L. D., Pifer, M. J., Colbeck, C., and Furman, T.: Increasing diversity in the geosciences: Recruitment programs and student self-efficacy, J. Geosci. Ed., 58, 32-42, 2010.

Bailey, C. M., Southworth, S., and Tollo, R. P.: Tectonic history of the Blue Ridge, north-central Virginia, in: Excursions in Geology and History: Field Trips in the Middle Atlantic States, GSA Field Guide 8, edited by: Pazzaglia, F. J., 113-134, https://doi.org/10.1130/2006.fld008(07), 2006.

Bartholomew, M. J. and Whitaker, A. E.: The Alleghanian deformational sequence at the foreland junction of the Central and Southern Appalachians, in: From Rodinia to Pangea; the lithotectonic record of the Appalachian region, edited by: Tollo, R. P., Bartholomew, M. J., Hibbard, J. P., and Karabinos, P. M., GSA Memoir, 206, 431-454, 2010.

Bernard, R. E. and Cooperdock, E. H. G.: No progress on diversity in 40 years, Nat. Geosci., 11, 292-295, https://doi.org/10.1038/s41561-018-0116-6, 2018.

Bloom, B. S., Engelhart, M. D., Furst, E. J., Hill, W. H., and Krathwohl, D. R.: Taxonomy of educational objectives: The classification of educational goals, Handbook I: Cognitive domain. New York, David McKay Company, ISBN OCLC:1110235218, 1956. 
Bond, C. E. and Cawood, A. J.: A role for virtual outcrop models in blended learning - improved 3D thinking and positive perceptions of learning, Geosci. Commun., 4, 233-244, https://doi.org/10.5194/gc-4-233-2021, 2021.

Bosch, R.: Development and implementation of virtual field teaching resources: two karst geomorphology modules and three virtual capstone pathways, Geosci. Commun., 4, 329-349, https://doi.org/10.5194/gc-4-329-2021, 2021.

Brush, J. A., Pavlis, T. L., Hurtado, J. M., Mason, K. A., Knott, J. R., and Williams, K. E.: Evaluation of field methods for 3-D mapping and 3-D visualization of complex metamorphic structure using multiview stereo terrain models from ground-based photography, Geosphere, 15, 188-221, https://doi.org/10.1130/GES01691.1, 2018.

Burke, K. and Dewey, J. F.: Hot spots and continental breakup: implications for collisional orogeny, Geology, 2, 57-60, 1974.

Carabajal, I. G., Marshall, A. M., and Atchison, C. L.: A synthesis of instructional strategies in geoscience education literature that address barriers to inclusion for students with disabilities, J. Geosci. Ed., 65, 531-541, 2017.

Carson R.: The Sense of Wonder, Harper and Row, ISBN -06757520-X, 1965.

Cawood, A. J., Bond, C. E., Howell, J. A., Butler, R. W. H., and Totake, Y.: LiDAR, UAV or compass-clinometer? Accuracy, coverage and effects on structural models, J. Struct. Geol., 98, 67-82, https://doi.org/10.1016/j.jsg.2017.04.004, 2017.

Clancy, K. B. H., Nelson, R. G., Rutherford, J. N., and Hinde, K.: Survey of Academic Field Experiences (SAFE): Trainees Report Harassment and Assault, PLoS ONE, 9, e102172, https://doi.org/10.1371/journal.pone.0102172, 2014.

Coe, A., Bosence, D. W. J., Church, K. D., Flint, S. S., Howell, J. A., and Wilson, R. C. L.: The Sedimentary Record of SeaLevel Change, Cambridge University Press, p. 288, ISBN 0-52153843-4, 2003.

Coe, A. L.: Geological field techniques, Wiley-Blackwell, p. 336, ISBN 1-444-33062-4, 2010.

Compton, R. R.: Geology in the field, Wiley, p. 416, ISBN 0-47182902-1, 1985.

Cooper, B. N. and Cooper, G. A.: Lower Middle Ordovician stratigraphy of the Shenandoah Valley, Virginia, Bull. Geol. Soc. Am., 57, 35-114, 1945.

Dennison, J. M. and Head, J. W.: Sealevel variations interpreted from the Appalachian basin Silurian and Devonian, Am. J. Sci., 275, 1089-1120, 1975.

De Paor, D. G. and Whitmeyer, S. J.: Innovations and Redundancies in Geoscience Field Courses: Past Experiences and Proposals for the Future, in: Field Geology Education: Historical Perspectives and Modern Approaches, edited by: Whitmeyer, S. J., Mogk, D., and Pyle, E. J., GSA Special Paper 461, 45-56, https://doi.org/10.1130/2009.2461(05), 2009.

Diecchio, R. J.: Stratigraphic interpretation of the Ordovician of the Appalachian Basin and implications for Taconian flexural modeling, Tectonics, 12, 1410-1419, https://doi.org/10.1029/93TC01791, 1993.

Egger, A., Atchison, C., Burmeister, K. C., Rademacher, L., Ryker, K., and Tikoff, B.: Teaching with Online Field Experiences: New resources by the community, for the community, In The Trenches, 11, available at: https://nagt.org/nagt/publications/ trenches/v11-n1/online_field_experiences.html, last access: 21 December 2021.

Evans, M. A.: The structural geometry and evolution of foreland thrust systems, northern Virginia, GSA Bull., 101, 339-354, https://doi.org/10.1130/00167606(1989)101<0339:TSGAEO>2.3.CO;2, 1989.

Fichter, L. S., Whitmeyer, S. J., Bailey, C. M., and Burton, W.: Stratigraphy, Structure, and Tectonics: An East to West Transect of the Blue Ridge and Valley and Ridge Provinces of Northern Virginia and West Virginia, in: The Mid-Atlantic Shore to the Appalachian Highlands: Field Trip Guidebook for the 2010 Joint Meeting of the Northeastern and Southeastern GSA Sections, editors: Fleeger, G. M. and Whitmeyer, S. J., GSA Field Guide 16, 103-125, https://doi.org/10.1130/2010.0016(05), 2010.

Giles, S., Jackson, C., and Stephen, N.: Barriers to fieldwork in undergraduate geoscience degrees, Nat. Rev. Earth Environ., 1, 7778, https://doi.org/10.1038/s43017-020-0022-5, 2020.

Gregory, D. D., Tomes, H. E., Panasiuk, S. L., and Andersen, A. J.: Building an online field course using digital and physical tools including VR field sites and virtual core logging, J. Geosci. Ed., https://doi.org/10.1080/10899995.2021.1946361, in press, 2021.

Himus, G. W. and Sweeting, G. S.: The Elements of Field Geology, 2nd Edn., University Tutorial Press, London, 1955.

Humphrey, E. A. and Wiles, J. R.: Lessons learned through listening to biology students during a transition to online learning in the wake of the COVID-19 pandemic, Ecol. Evol., 11, 3450-3458, https://doi.org/10.1002/ece3.7303, 2021.

Hurst, S. D.: Use of "virtual" field trips in teaching introductory geology, Comput. Geosci., 7, 653-658, 1998.

Jacobson, A. R., Militello, R., and Baveye, P. C.: Development of computer-assisted virtual field trips to support multidisciplinary learning, Comput. Educ., 52, 571-580, https://doi.org/10.1016/j.compedu.2008.11.007, 2009.

Kastens, K. A., Manduca, C. A., Cervato, C., Frodeman, R., Goodwin, C., Liben, L. S., Mogk, D. W., Spangler, T. C., Stillings, N. A., and Titus, S.: How geoscientists think and learn, EOS Trans. Am. Geophys. Union, 90, 265-272, 2009.

LaDue, N. D. and Pacheco, H. A.: Critical Experiences for Field Geologists: Emergent Themes in Interest Development, J. Geosci. Ed., 61, 428-436, 2013.

Masters, B., Bursztyn, N., Rieel, H. B., Huang, J., Sajjadi, P., Bagher, M., Zhao, J., La Femina, P., and Klippel, A.: Science education through virtual experiences - The strike and dip (SAD) tool, GSA Abstracts with Programs, 52, https://doi.org/10.1130/abs/2020AM-359969, 2020.

McClung, W. S., Eriksson, K. A., Terry Jr., D. O., and Cuffey, C. A.: Sequence stratigraphic hierarchy of the Upper Devonian Foreknobs Formation, central Appalachian Basin, USA: evidence for transitional greenhouse to icehouse conditions, Palaeogeogr. Palaeocl., 387, 104-125, 2013.

Mead, C., Buxner, S., Bruce, G., Taylor, W., Semken, S., and Anbar, A. D.: Immersive, interactive virtual field trips promote science learning, J. Geosci. Educ., 67, 131-142, https://doi.org/10.1080/10899995.2019.1565285, 2019.

Mikropoulos, T. A. and Natsis, A.: Educational virtual environments: A ten-year review of empirical research (1999-2009), Comput. Educ., 56, 769-780, https://doi.org/10.1016/j.compedu.2010.10.020, 2011. 
Mogk, D. W. and Goodwin, C.: Learning in the field: Synthesis of research on thinking and learning in the geosciences, in: Earth and mind II: A synthesis of research on thinking and learning in the geosciences, edited by: Kastens, K. A. and Manduca, C. A., GSA Special Paper 486, 131-163, https://doi.org/10.1130/2012.2486(24), 2012.

Orion, N. and Hofstein, A.: Factors that influence learning during a scientific field trip in a natural environment, J. Res. Sci. Teach., 31, 1097-1119, 1994.

Passchier, C. W. and Simpson, C.: Porphyroclast systems as kinematic indicators, J. Struct. Geol., 8, 831-843, 1986.

Perry Jr., W. J.: Sequential deformation in the central Appalachians, Am. J. Sci., 278, 518-542, 1978.

Petcovic, H. L., Stokes, A., and Caulkins, J. L.: Geoscientists' perceptions of the value of undergraduate field education, GSA Today, 24, 7, https://doi.org/10.1130/GSATG196A.1, 2014.

Pickrell, J.: Scientists push against barriers to diversity in the field sciences, Science, 374, 375, https://doi.org/10.1126/science.caredit.abb6887, 2020.

Posamentier, H. W. and Walker, R. G.: Faces models revisited, SEPM Sp. Pub. 84, p. 532, ISBN 1-56576-121-9, 2006.

Quigley, M.: Small wins: undergraduate geological field trips in times of COVID-19, Speaking of Geoscience, GSA Guest Blog, available at: https://speakingofgeoscience.org/2021/07/21/smallwins-undergraduate-geological-field-trips-in-times-of-, covid19/, last access: 21 December 2021.

Race, A. I., De Jesus, M., Beltran, R. S., and Zavaleta, E. S.: A comparative study between outcomes of an in-person versus online introductory field course, Ecol. Evol., 11, 3625-3635, https://doi.org/10.1002/ece3.7209, 2021.

Rotzien, J. R., Sincavage, R., Pellowski, C., Gavillot, Y. Filkorn, H., Cooper, S., Shannon, J., Yildiz, U. Sawyer, F., and Uzunlar, N.: Field-Based Geoscience Education during the COVID-19 Pandemic: Planning, Execution, Outcomes, and Forecasts, GSA Today, 31, 4-10, https://doi.org/10.1130/GSATG483A.1, 2021.

Southworth, S., Aleinikoff, J. N., Tollo, R. P., Bailey, C. M., Burton, W. C., Hackley, P. C., and Fanning, C. M.: Mesoproterozoic magmatism and deformation in the northern Blue Ridge, Virginia and Maryland: Application of SHRIMP U-Pb geochronology and integrated field studies in the definition of Grenvillian tectonic history, in: From Rodinia to Pangea: The Lithotectonic Record of the Appalachian Region, editors: Tollo, R. P., Bartholomew, M. J., Hibbard, J. P., and Karabinos, P. M., GSA Memoir, 206, 795836, https://doi.org/10.1130/2010.1206(31), 2010.

Stokes, P., Levine, R., and Flessa, K. W.: Choosing the geoscience major: Important factors, race/ethnicity, and gender, J. Geosci. Educ., 64, 101-107, https://doi.org/10.1177/105382590102400307, 2015.
Van Wagoner, J .C.: Sequence stratigraphy and marine to nonmarine facies architecture of foreland basin strata, Book Cliffs, Utah, U.S.A, in: Sequence stratigraphy of foreland basin deposits, edited by: Van Wagoner, J. C. and Bertram, G. T., AAPG Memoir, 64, 137-224, 1995.

Van Wagoner, J. C., Mitchum, R. M., Campion, K. M., and Rahmanian, V. D.: Siliciclastic sequence stratigraphy in well logs, cores, and outcrops: Concepts for high resolution correlation of time and facies, AAPG Methods in Exploration, 7, p. 55, https://doi.org/10.1306/Mth7510, 1990.

Whitmeyer, S. J. and Dordevic, M.: Creating Virtual Geologic Mapping Exercises in a Changing World, Geosphere, 17, 226-243, https://doi.org/10.1130/GES02308.1, 2021.

Whitmeyer, S. J. and Fichter, L. S.: Integrating structural and stratigraphic field data to build a tectonic model for the MidAtlantic Appalachian orogenic cycle, in: Problems and Solutions in Structural Geology and Tectonics, edited by: Billi, A. and Fagereng, A., Dev. Struct. Geo. Tect., 5, 161-177, https://doi.org/10.1016/B978-0-12-814048-2.00013-2, 2019.

Whitmeyer, S. J., Mogk, D. W., and Pyle, E. J.: An Introduction to historical perspectives on and modern approaches to Field Geology Education, in: Field Geology Education: Historical Perspectives and Modern Approaches, edited by: Whitmeyer, S. J., Mogk, D., and Pyle, E. J., GSA Special Paper 461, vii-x, https://doi.org/10.1130/2009.2461(00), 2009.

Whitmeyer, S. J., Bailey, C. M., and Spears, D. B.: A billion years of deformation in the central Appalachians: Orogenic processes and products, in: Tripping from the Fall Line: Field Excursions for the GSA Annual Meeting, Baltimore, 2015, edited by: Brezinski, D. K., Halka, J. P., and Ortt Jr., R. A., GSA Field Guide, 40, $11-$ 34, https://doi.org/10.1130/2015.0040(02), 2015.

Whitmeyer, S. J., Atchison, C., and Collins, T. D.: Using mobile technologies to enhance accessibility and in clusion in field-based learning, GSA Today, 30, 4-10, https://doi.org/10.1130/GSATG462A.1, 2020.

Wilson, J. T.: Did the Atlantic Close and then Re-Open?, Nature, 211, 676-681, https://doi.org/10.1038/211676a0, 1966.

Xie, X. and Heller, P. L.: Plate tectonics and basin subsidence history, GSA Bull., 121, 55-64, https://doi.org/10.1130/B26398.1, 2009.

Young, D. A.: Mind over magma: the story of igneous petrology, Princeton University Press, Princeton, NJ, ISBN 9780691102795, 2003. 